Vol. 5, No. 1, 2021

UDK 332.145

JEL Classification Code E20, E66, F43, I38, 018

\author{
O. Grytsay ${ }^{1}$, I. Hrytsai ${ }^{2}$ \\ Lviv Polytechnic National University \\ Department of Accounting and Analysis \\ ORCID: ${ }^{1}$ 0000-0001-6305-9219, ${ }^{2}$ 0000-0003-0630-1317
}

\title{
SOCIO-ECONOMIC ANALYSIS OF THE CURRENT STATE AND PROSPECTS OF DEVELOPMENT OF THE ZAKARPATTIA REGION
}

http://doi.org/10.23939/semi2021.01.030

(C) Grytsay O., Hrytsai I., 2021

Purpose. The study's purpose is a socio-economic analysis of the Zakarpattia region's current state of development to determine the factors that affect the current situation and priority areas for improving the territorial organization Zakarpattia region, which will ensure sustainable regional development.

Design/methodology/approach. In the article, the authors used the literature review method to identify the state of research on socio-economic development of the regions of Ukraine and to justify the importance of separate consideration of the dynamics of macroeconomic indicators. As a result of the analysis of scientific literature sources on the issue of socio-economic development of the Carpathian region of Ukraine, it was revealed that empirical studies of statistical data are insufficiently presented.

Based on the comparative method, system analysis, and synthesis, the leading statistical indicators of the Zakarpattia region are studied: gross regional product (GRP), inflation, the economic activity of the population, unemployment, level of consumer prices, capital investments, foreign economic activity, household expenditures, level of wages and incomes of the people for 2007-2019, the dynamics of which reflects two crisis periods: 2008 and 2014-2015. Economic development dynamics in conditions of political instability and rapid changes in the external environment show positive macroeconomic changes reflected in GDP growth, wage growth, increasing exports, and the excess of exports over imports.

Findings. The hypothesis that the focus of achieving the most efficient use of the region's potential and its balanced development is possible only based on coordination of economic, social, and environmental interests, both at the regional and national levels. In particular, the study of GRP of the Zakarpattia region during 2007-2019 shows a stable growth of the area's nominal GRP. However, the real GRP at the same time, although fluctuating abruptly and in general, remains virtually unchanged. A study of the share of the Zakarpattia region's economically active population in the structure of the economically active population of Ukraine allows us to conclude that it has changed unevenly and has tended to decrease. The border location of the Zakarpattia region facilitated emigration. In 2020, the share of the economically active population was declining, and unemployment is rising due to the loss of many people of their jobs due to the pandemic, which directly impacts reducing real and nominal GRP. Today's economic recovery is taking place without significant changes in domestic enterprises' quantitative structure by industry and is not accompanied by an increase in foreign investment. 
Practical implications. The results of this research are of interest to scientists and students of educational institutions, employees of research institutions that study the development trends of the regions of Ukraine. Besides, the results can help employees of public authorities of the Zakarpattia region shape the area's development strategy.

Originality/value. This study highlights the strengthening of globalization processes at the present stage of development of our state puts before its regions the main requirement - to maintain and streng then the positive growth of vital socio-economic indicators through the introduction of administrative, legal, tax, financial and other measures in the interests of the population and the state as a whole. The main factors influencing the socio-economic development of the Zakarpattia region are identified. Thus, based on the analysis, we can conclude that the Zakarpattia region's socio-economic development will depend on the dynamics of production and consumption and improve the results of foreign economic activity. Priority areas for improving the Zakarpattia region's territorial organization, which will ensure regional development sustainability, have been identified. The unique geopolitical location of Zakarpattia region and its agricultural orientation and tourism are decisive factors in overcoming crises and reviving its socio-economic development.

Key words: economic development of the region; GRP; inflation; the economic activity of the population; unemployment; level of consumer prices; capital investments; foreign economic activity; household expenditures; level of wages and incomes of the population.

Paper type: Research paper.

\section{Formulation of the problem}

The article aims to study the Zakarpattia region's statistical indicators to assess the area's level of development and identify the main economic processes and causes that caused the current situation.

\section{Analysis of recent research and publications}

Recently, there has been an increase in scientific research in the regional socio-economic development of our state. A large number of scholars, in particular I. Alieksieiev [1], L. Savchuk [2], and others focus on financing the territorial development of regions. Possibilities of increasing the competitiveness of areas were considered in the works of O. Kuzmin and N. Stanasiuk [3], in particular through the tourism sector - O. Karyy [4], M. Odrekhivskyi [5], A. Terebuh [6]. The problems of reviving the development of the Carpathian region in their works were raised by the following Ukrainian scientists M. Odrekhivskyi [7], L. Shevchuk [8], I. Irtyshcheva [9], G. Bilak [10], V. F. Proskura [11], I. Chuchka [12]. Peculiarities of the development of the agricultural sector regions were studied by O. Varchenko [13], S. Kozlovskyi [14].

Despite numerous scientific studies, the issue of the impact of the dynamics of macroeconomic changes in the regions on their socio-economic development remains unresolved. Scientists' judgments are based more on subjective perceptions and experience than on empirical research. These and other reasons condition a separate consideration of regional socio-economic development dynamics, which will allow assessing macroeconomic changes in the region.

However, an up-to-date assessment of the current state and prospects of the region's development can be made only by identifying the main economic processes and the reasons that caused the current situation.

\section{Hypothesis formulation and goal setting}

The study's general hypothesis is that achieving the most efficient use of the region's potential and its balanced development is possible only based on coordination of economic, social, and environmental interests, both at the regional and national levels.

The study's primary purpose is to analyze the leading macroeconomic indicators, reflecting the region's socio-economic development.

Research methods: literature review, comparative, system analysis and synthesis, scientific abstraction. 
O. I. Grytsay, I. A. Hrytsai

$\frac{\sqrt{2}}{\frac{2}{3}}$

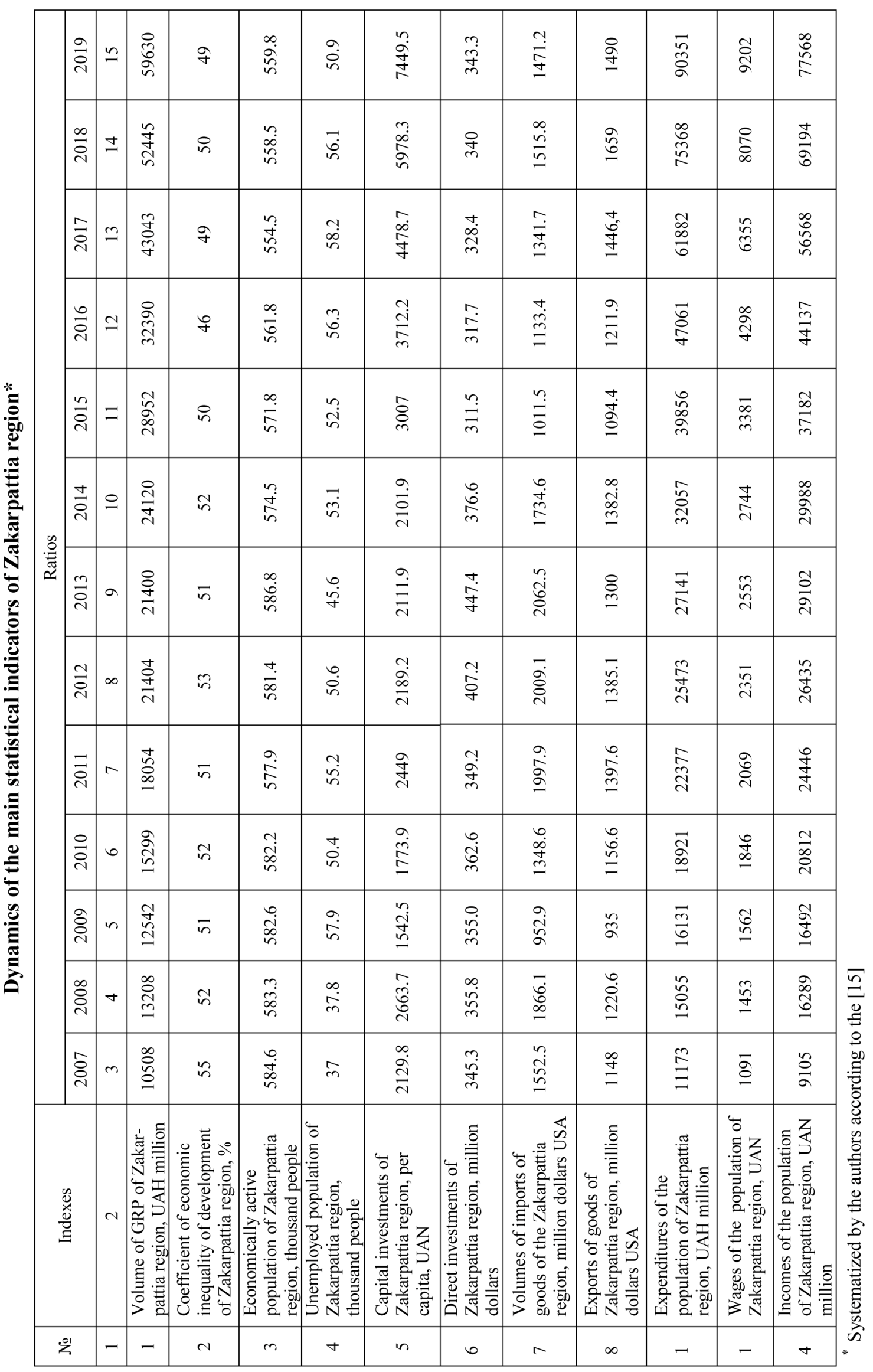




\section{Main part}

Assessment of regions economic development, primary directions, and reasons for various changes should be carried out through the prism of the study of such general economic phenomena as national income (NI), gross regional product (GRP), inflation, economic activity, unemployment, consumer prices, capital investment, foreign economic activity, household expenditures, the level of wages and incomes, etc. The results of the analysis of these indicators for 2007-2019 are shown in Table 1.

The main form of management in the Zakarpattia region is personal households working in the field of agriculture. Significant volumes of crop production in the area are grown in the foothills' difficult climatic conditions with rugged terrain and small parcels, which are risky and negatively affected by external factors, including weather conditions [16].

During the analyzed period 2007-2019, the Zakarpattia region's agricultural production structure remained a relatively uniform distribution of crop and livestock products.

The advantages of the region's border location and natural features, and labor potential should be used to implement investment projects in the area, the performance of cross-border infrastructure projects to increase its economic potential and prosperity.

The region's favorable location promotes cross-border cooperation and European integration, stimulates the sale of goods and services produced in rural areas, and attracts foreign investment in agricultural production in the region.

Solving recreational areas' problems and using the potential of thermal sources and logistics will also raise the region's tourist attractiveness. With Ukraine's accession to the WTO, Zakarpattia farmers must reorganize their activities following international standards. Implementing these measures will provide all the prerequisites for increasing farmers' profitability, increasing production and sales, thereby ensuring the region's sustainable development.

Gross regional product is one of the most critical economic development indicators: the total market value of all final goods and services produced by residents of the country in its territory for a certain period. The dynamics of nominal and real GRP for the period under study is shown in Fig. 1 and Fig. 2.

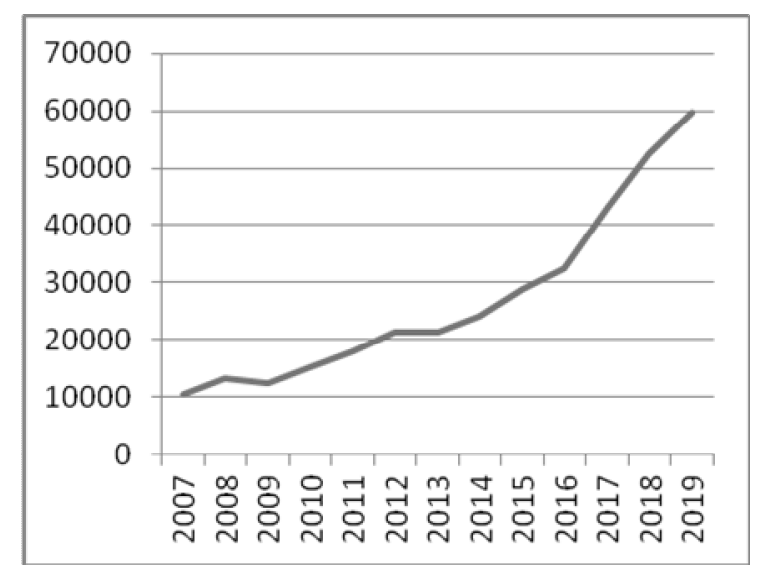

Fig. 1. Dynamics of change in the volume of nominal GRP of Zakarpattia region, UAN million [17]

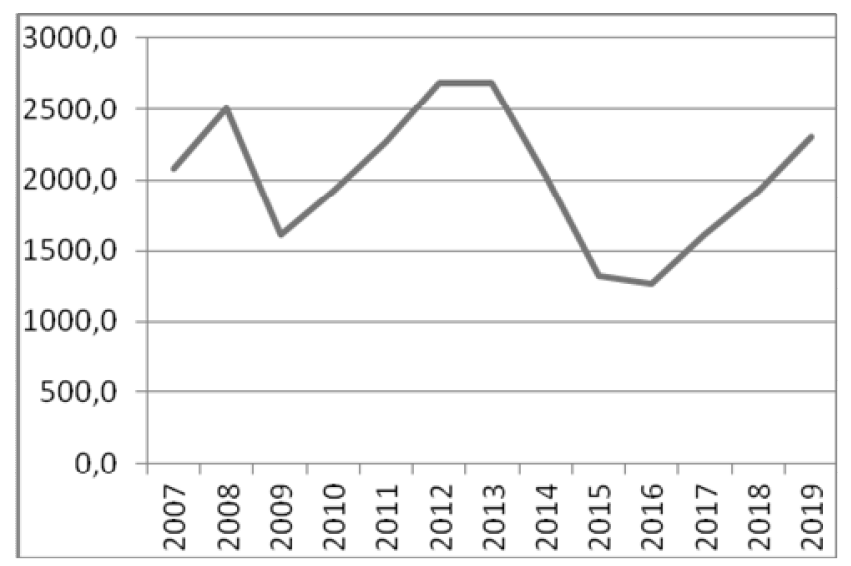

Fig. 2. Dynamics of change in the volume of real GRP of Zakarpattia region, USD million [17]

The study of GRP of the Zakarpattia region during 2007-2019 shows a stable growth of the area's nominal GRP. However, the nominal GRP does not adequately reflect the economic situation in the region. The dynamics of the accurate GRP indicator reflect two crisis periods: 2008 and 2014-2015. In 2008, under the influence of the global financial and economic crisis and the hryvnia's devaluation, real GDP declined. The problem of 2014-2015 was caused by civil resistance in the country and the conflict with Russia, and the annexation of Crimea. The cessation of export-import operations with Russia has led to structural changes in production volumes, particularly in the Zakarpattia region. We can assume 


\section{O. I. Grytsay, I. A. Hrytsai}

that the increase in nominal GRP is caused by inflation. The period 2009-2014 is characterized by the rise in real GRP caused by the rise in production. In 2012-2013, both nominal and real GRP of the Zakarpattia region remained unchanged because these two years in a row were productive. There was no inflation, and a large share of agricultural production characterizes the study area. The growth of both natural and nominal GRP in 2016-2019 was caused by monetary policy, the dollar's release into "free circulation", devaluation is restrained, export sare growing, imports of finished products are declining the reorientation to domestic consumption. The GRP of the Zakarpattia region in the GRP structure of Ukraine during the studied period was stable. It amounted to $1.4-1.5 \%$, due to the small area, part of which cannot be actively used, and the small number of inhabitants of the region. Examining the coefficient of economic inequality of the Zakarpattia region, we observe its fluctuations in the range of 46$55 \%$, which indicates that the Zakarpattia region is an agricultural region. The largest gross share in the structure of the region's land fund is occupied by forests and other wooded areas $-56.7 \%$, agrarian land $35.3 \%$, built-up land $-4.0 \%$, and others.

The following important factor in the study of the Zakarpattia region's socio-economic development is the study of the dynamics of economic activity and unemployment.

The study of the share of the Zakarpattia region's economically active population in the structure of the economically active population of Ukraine allows us to conclude that it tends to increase after 2014. The share of the Zakarpattia region's economically active population is about $3 \%$ due to the small population, agricultural specialization of the area, and the impossibility of active use of all land plots.

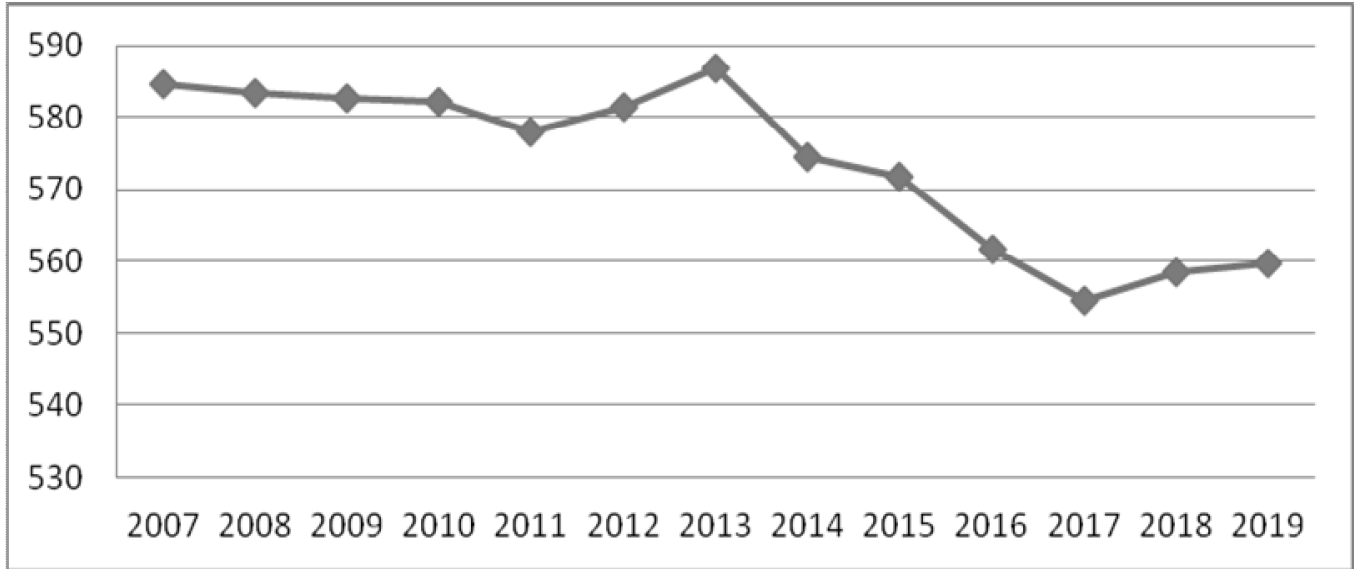

Fig. 3. Dynamics of economically active population of Zakarpattia region, thousand people [17]

As shown in Fig. 3, the number of the Zakarpattia region's economically active population during 2007-2019 changed unevenly and generally tended to decrease. A slight decrease in the number of the economically active population after the crisis of 2008-2009 is due to the reduction of production and emigration, which was facilitated by the border location of the Zakarpattia region. The sharp decrease in the number of the economically active population of the Zakarpattia region after 2014, in addition to these factors, was due to the mobilization of an economically active population as a result of hostilities in eastern Ukraine.

Analyzing the share of the Zakarpattia region's unemployed population, it can be argued that its importance remained stable during 2007-2020. The growth was observed in 2011-2012, but from 2019 it decreases again. As shown in Fig. 4, the number of unemployed in the Zakarpattia region fluctuates throughout the study period.

The share of the economically active population is declining in 2020, and unemployment is rising due to the loss of many people their jobs due to the pandemic, which will reduce the employed population and have a significant direct impact on lowering real and nominal GRP. 
Socio-economic analysis of the current state and prospects of development of the Zakarpattia region

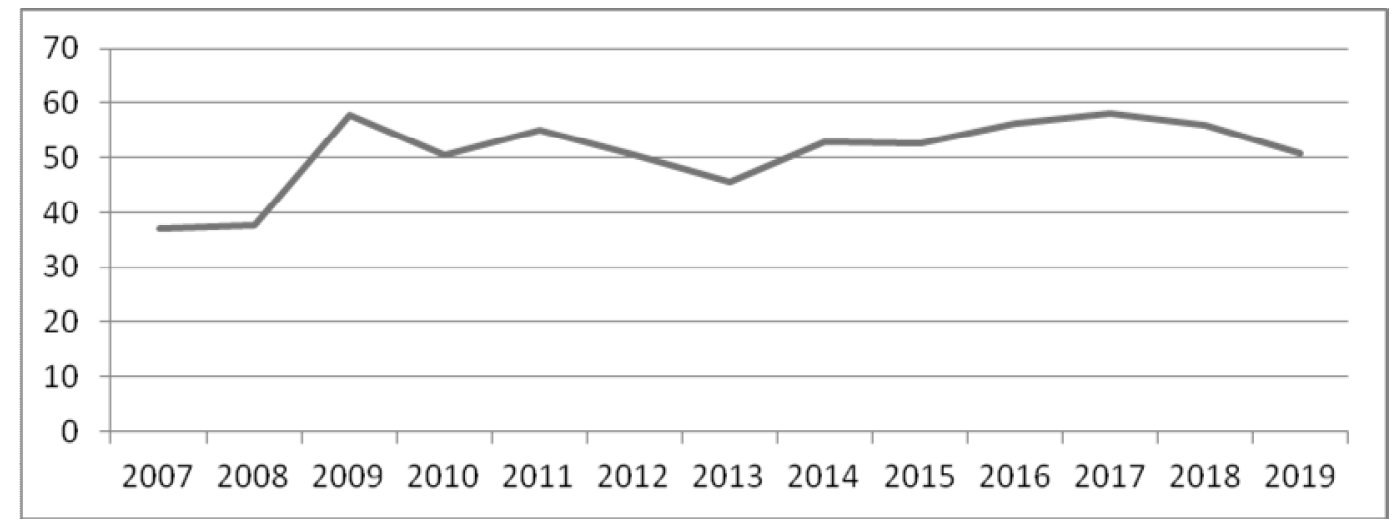

Fig. 4. Dynamics of Unemployed population of Zakarpattia region, thousands of people [15]

The rapid rise in unemployment in 2009 is a sign of the global financial crisis, which was marked by a decline in production and reduced the number of jobs. The stabilization of the economy in the post-crisis period reduced the number of unemployed in 2012-2013. After the crisis of 2014, there is an increase in unemployment, which is partially reduced in 2018 due to the revival of economic development, as well as the mobilization of unemployed men.

In our opinion, the activities of the state policy to stimulate employment should be aimed at:

- professional training and retraining of the population;

- providing jobs for people with limited use of labor potential;

- encouraging the unemployed to look for work;

- organization of paid public works;

- improving the quality of created jobs.

The consumer price index (CPI) measures changes in the weighted average basket of consumer goods and services purchased by households. As shown Fig. 5, the CPI Zakarpattia region's CPIctuates throughout the study period.

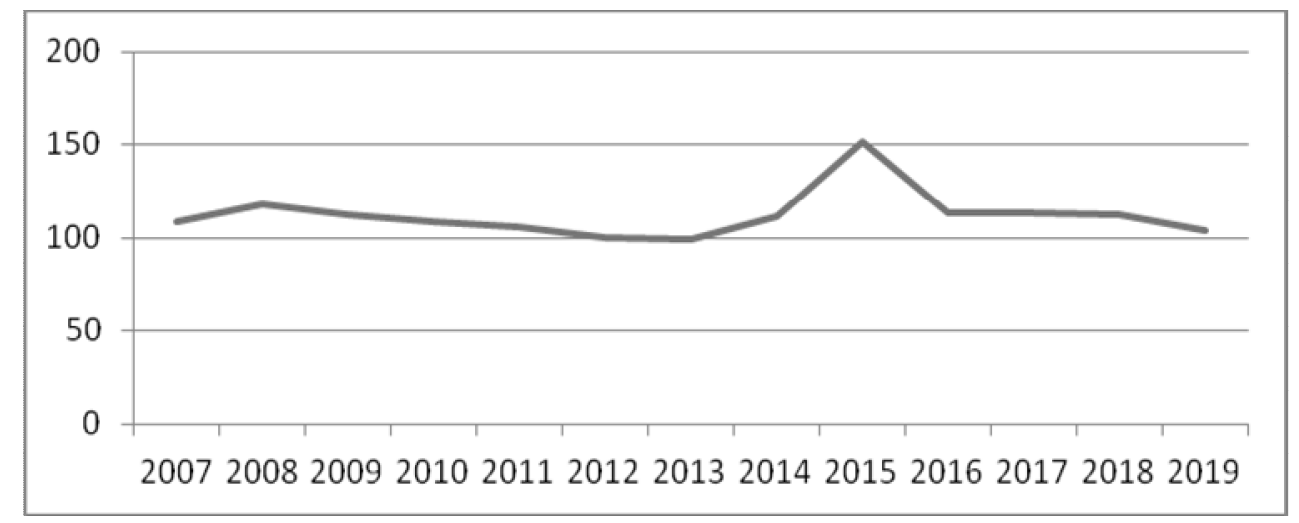

Fig. 5. Consumer Price Index of Zakarpattia region, \% [15]

Analyzing the dynamics of the CPI in the region, we can observe an increase in the consumer price index in 2008, which means inflation in this period, the devaluation of the hryvnia and reduced production in the country and in the Zakarpattia region, which is a sign of global financial crisis in 2008. In 20092011 we can see a way out of the economic crisis and the normalization of the economy, during this period inflation still existed, but tended to decrease. Analyzing the Fig. 5, there is deflation in 2012-2013. It can be argued that the largest deflation took place in the agricultural regions of Ukraine, one of which is the Zakarpattia region. This is due to the reduction of the cost of agricultural products, which is the main share 


\section{O. I. Grytsay, I. A. Hrytsai}

in the structure of the consumer basket. In 2014-2015, we can also observe inflation, which is a sign of the devaluation of the hryvnia and the crisis in 2014-2015. In 2016-2020, we see from the Fig. 5 a decrease in inflation, which indicates a way out of the economic crisis and economic growth.

Investments relate to the acquisition of land, machinery, buildings and equipment by firms, which all increase the capital of firms. The dynamics of changes in capital and foreign direct investment can be seen in Fig. 6 and Fig. 7.

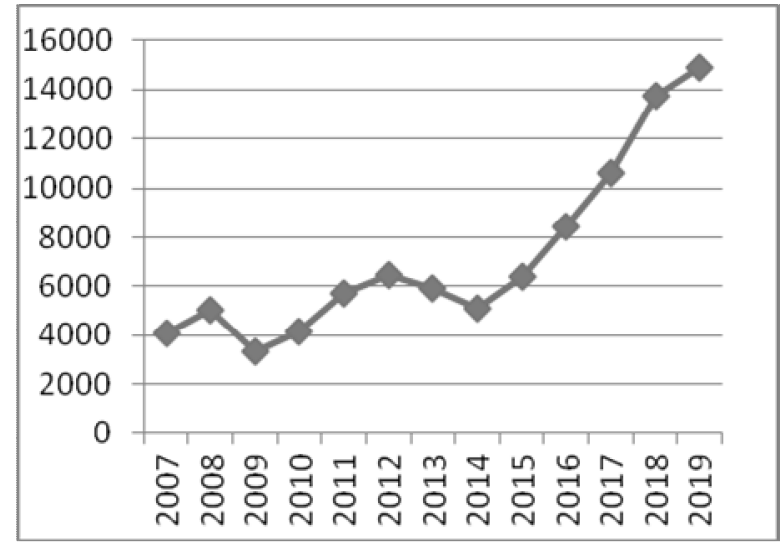

Fig. 6. Capital investments of Zakarpattia region 1 person, $U A H$ [15]

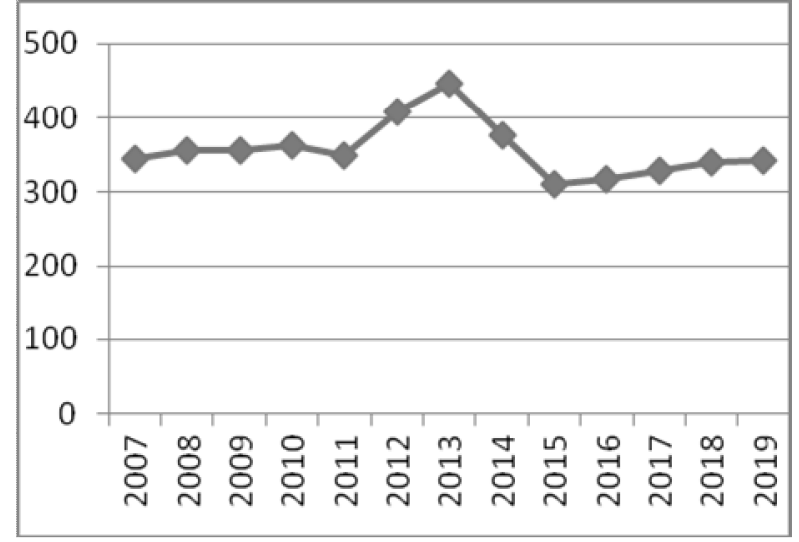

Fig. 7. Direct investments of Zakarpattia region, million USD [15]

Analyzing the dynamics of capital investments in the Zakarpattia region for 2007-2019, we can observe slight fluctuations in investment during 2007-2014. During this period, the situation was economically unstable, namely the two crisis periods in 2008 and 2014, which led to a decrease in investment in enterprises' development due to lack of funds and unpredictability of the situation. However, in 2015-2019 there is a steady increase in capital investment in the Zakarpattia region. On the one hand, this is due to the stabilization of the economy, the way out of the crisis, and, on the other hand, to the high level of inflation at this time. The share of capital investments in the Zakarpattia region in the structure of capital investments in Ukraine ranges from $34 \%$ to $52 \%$. The small percentage of capital investments in the area is due to its insignificant development and agricultural orientation.

The inflow of investments, in particular foreign ones, according to scientists [18], may increase due to the implementation of land reform. However, the benefits of this are pretty questionable and debatable, which is discussed in detail in the work of L. Pylypenko and B. Ilychok [19].

The share of foreign direct investment in the Zakarpattia region in the structure of direct investment of Ukraine during 2007-2019 is insignificant. It ranges from $0.7 \%$ to $1.2 \%$, primarily due to the region's agricultural orientation, as direct investment, as a rule, focused, industry-oriented. As shown in Fig. 7, a sharp decline in foreign direct investment in the Zakarpattia region was observed in 2014-2015 due to the unstable situation in Ukraine. Since 2016, there has been an increase in foreign direct investment due to economic stabilization and exit from the crisis. No less critical factor determining the growth of foreign direct investment in this period is the Zakarpattia region's border location in western Ukraine. In 2017, the Association Agreement between Ukraine and the European Union entered into force, which stimulated direct investment.

The study of the dynamics of foreign economic activity, particularly in exports, imports, and net exports of the Zakarpattia region, is shown in Fig. 8.

As we can see, the volume of imports prevails over the importance of exports, so the net export indicator is primarily negative. In 2009, there was a decrease in exports and imports of goods, which indicates a global financial crisis. The period of 2010-2014 ischaracterized mainly by the growth of both exports and imports, which means stabilizing the economic situation and full membership of Ukraine in the WTO. In 2014-2015, we saw that exports slightly exceed imports and, as a result, net exports increase. It is 
worth mentioning the fighting in eastern Ukraine and the unstable economic situation in Ukraine and, in particular, the Zakarpattia region, the devaluation of the hryvnia, which led to higher prices for imported goods at this time. The period from 2016 to 2019 is characterized by an increase in exports and imports, which is associated with the Association Agreement's completionbetween Ukraine and the European Union and the stabilization of the economy. Let's analyze the ratio of exports of goods by enterprises in the region to the GRP of the part. We can see that the frequency is relatively high and averages $61 \%$, indicating the Zakarpattia region's border location, low consumption in the area due to the small population, and production ofgoods mainly for export. Analyzing the ratio of imports of goods by enterprises in the region to the GRP volume in the area, we see an even larger share than exports. It averages $76 \%$, which once again confirms the above factors

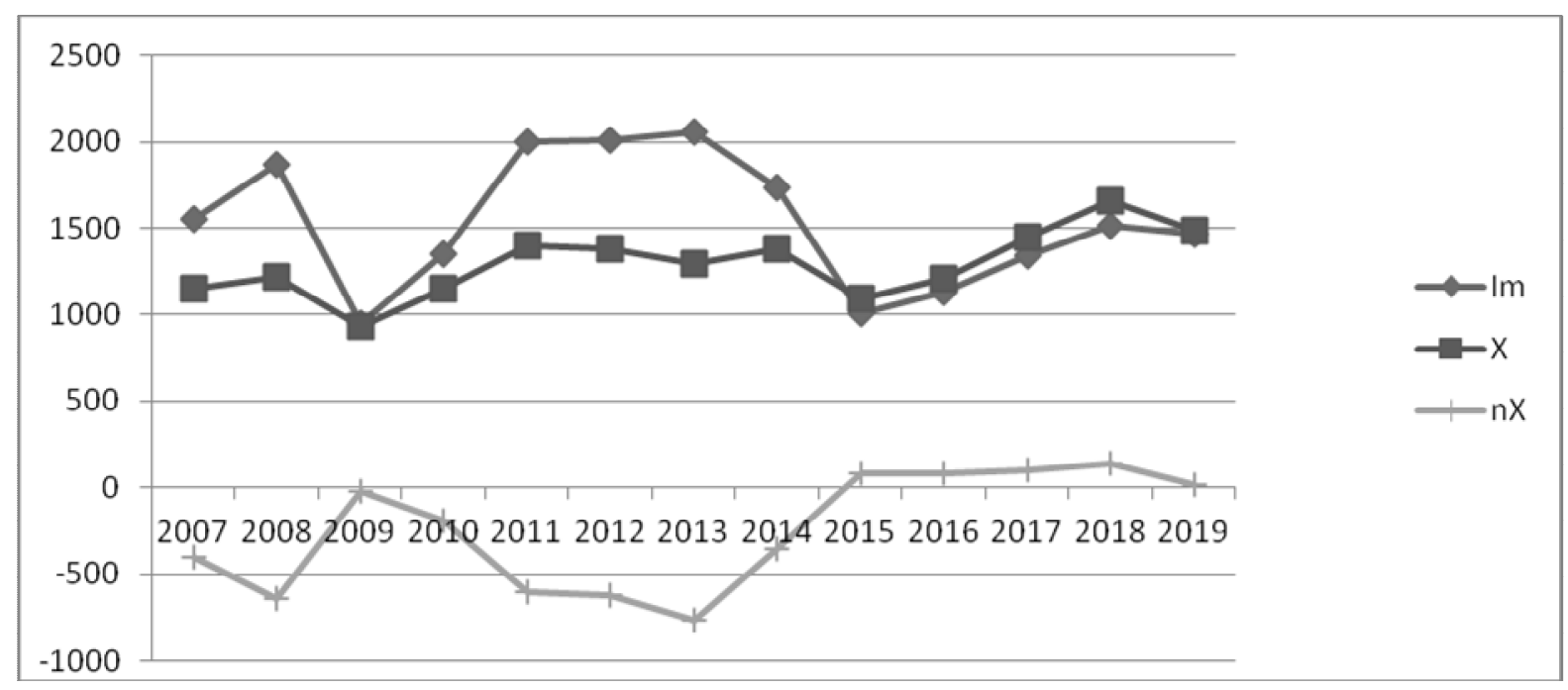

Fig. 8. Dynamics of exports, imports and net exports of Zakarpattia region, million dollars USA [20]

When studying the socio-economic indicators of development of the Zakarpattia region, it is necessary to pay attention to the population's level of income and expenditure. Income of the population is a set of monetary and in-kind incomes aimed at maintaining a person's physical, moral, and economic condition and meeting his needs. They are closely linked to the population's expenditures, which ensure GDP growth and, as a result, the development of the country's economy.

Analyzing Fig. 9 of expenditures of the Zakarpattia region population, we see that it tends to increase during the study period. This is since wages and prices for goods and services are constantly rising.

The share of expenditures of the Zakarpattia region population in Ukraine is $2 \%$, which indicates the rural orientation of the region and a small number of consumers.

Since the Zakarpattia region is a border region and a significant part of the population receives income abroad and consumes more imported goods and services than domestic, the share of population expenditures in the structure of GRP in the region exceeds $100 \%$.

The income of the population has an essential impact on the GRP of the region and thecountry's GDP as a whole because the more the population earns, the more it consumes and invests, and this ensures not only GRP growth but also filling state and local budgets with taxes.

If we analyze the share of income of the Zakarpattia region in the structure of payment of Ukraine, we see that it averages $2 \%$. This indicates the agricultural orientation of the area.

Analyzing the share of wages in the Zakarpattia region in Ukraine, we can observe fluctuations in the range of $77-91 \%$. This confirms that the population working in agriculture earns less than the population working in the industry. 


\section{O. I. Grytsay, I. A. Hrytsai}

Wages and incomes in the Zakarpattia region tend to increase throughout the study period. This is since the minimum wage is also constantly rising to support the purchasing power of the population. We can see this Fig. 10 and Fig. 11.

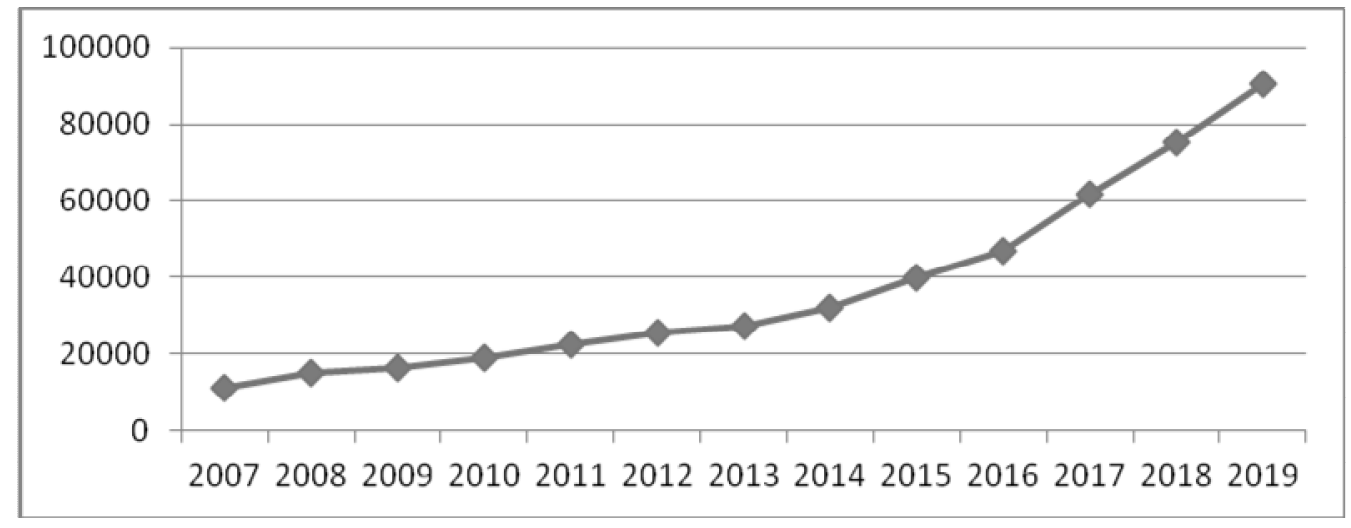

Fig. 9. Dynamics of expenses of households of Zakarpattia region, UAH million [15]

The income of the population has an important impact on the GRP of the region and the GDP of the country as a whole, because the more the population earns, the more it consumes and invests, and this ensures not only GRP growth but also filling state and local budgets with taxes.

If we analyze the share of income of the Zakarpattia region in the structure of income of Ukraine, we see that it averages $2 \%$. This indicates the agricultural orientation of the region.

Analyzing the share of wages in the Zakarpattia region in Ukraine, we can observe fluctuations in the range of 77-91\%. This once again confirms that the population working in agriculture earns less than the population working in industry.

Wages and incomes in the Zakarpattia region tend to increase throughout the study period. This is due to the fact that the minimum wage is also constantly rising to support the purchasing power of the population. We can see this Fig. 10 and Fig. 11.

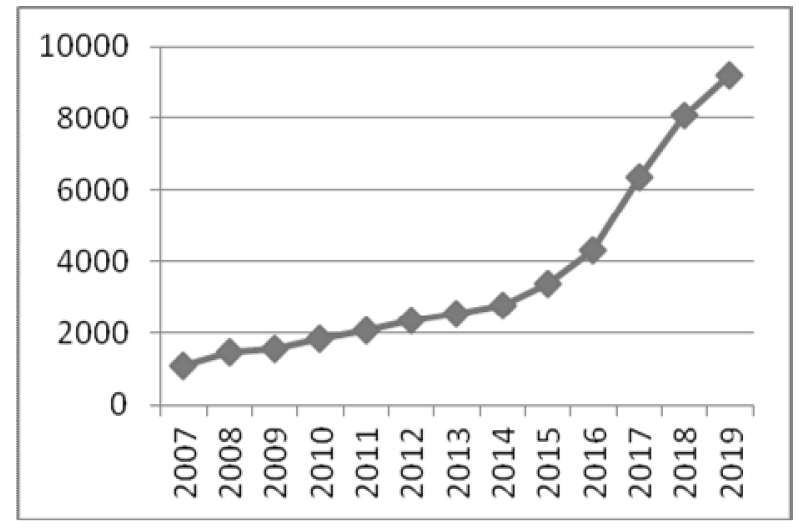

Fig. 10. Wages of the population of Zakarpattia, UAH [15]

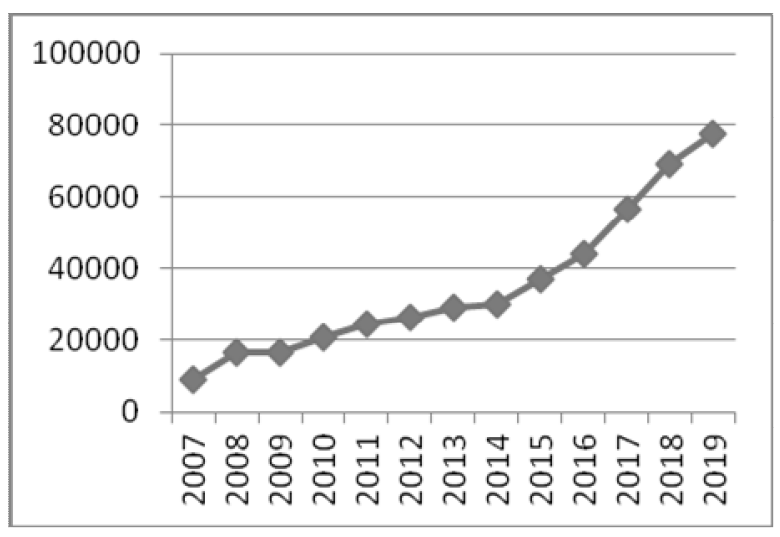

Fig. 11. Incomes of the population of Zakarpattia, UAH million [15]

\section{Conclusions}

The GRP of the Zakarpattia region during 2007-2019 shows a stable growth of the region's nominal GRP. However, the real GRP at the same time, although fluctuating abruptly and in general, remains virtually unchanged. 


\section{Socio-economic analysis of the current state and prospects of development of the Zakarpattia region}

During the analyzed period, the nominal GRP increased due to increased production, household expenditures, and growth of capital investments. Real GDP grew due to the rise in direct investment and employment.

A study of the share of the Zakarpattia region's economically active population in the structure of the economically active population of Ukraine allows us to conclude that it has changed unevenly, and in general, has tended to decrease. The border location of the Zakarpattia region facilitated emigration.

In 2020, the share of the economically active population was declining, and unemployment is rising due to the loss of many people of their jobs due to the pandemic, which directly impacts reducing real and nominal GRP.

The obtained results confirm the formed hypothesis that achieving the most efficient use of the region's potential and its balanced development is possible only based on coordination of economic, social, and environmental interests, both at the regional and national levels.

In our opinion, the priority areas for improving the territorial development of the Zakarpattia region, which will ensure the sustainability of regional development and reduce spatial asymmetry, should be:

- creation of conditions for modernization of industry, agriculture, support and development of their competitiveness based on clustering;

- capitalization of human resources and their distribution in the region, increasing the spatial and qualification mobility of the population;

- equalization of employment in the region; formation of infrastructure networks (production and economic, social, cultural, information);

- institutional integration (cooperation in the field of education and R\&D);

- cooperation in the implementation of infrastructure and road transport projects;

- creation of unified services for monitoring the state of socio-economic development of regional farms and territories; cluster development).

The Zakarpattia region's unique geopolitical location at the intersection of international transport, economic, trade, and cultural routes promotes interstate cooperation development.

\section{Prospects for further research}

In the future, it is planned to form a forecast of the dynamics of socio-economic development indicators, namely gross domestic product, gross regional product, average monthly wages in the short and long term.

1. Алєксєєв I. В. (2014). Бюджетний механізм і соціально-економічний розвиток регіонів: монографія. Львів: Ліга-Прес, 248 с.

2. Савчук Л. М. (2017). Економічна кібернетика: моделювання соціально-економічних систем: колективна монографія. Дніпро: Пороги, 480 c.

3. Kuzmin O. Y., Stanasiuk N. S., Yastrubskyi M. Y., Mohylevska O. Y., Artiushok V. S. (2020). Industrial potential: assessment, modeling and administration under the condition of sustainable development. Науковий вісник Наи гірничого ун-ту. № 6, С. 128-135. (Scopus)

4. Карий О. І., Глинський Н. Ю. (2020). Об’єднання зусиль територіальних громад з метою використання їх туристично-рекреаційного потенціалу. Ефективна економіка, № 5. Available at: http://www.economy. nayka.com.ua/?op=1\&z=7886

5. Odrekhivskyi Mykola, Kunanets Nataliia, Pasichnyk Volodymyr, Rzheuskyi Antonii, Tabachishin Danylo (2019). Information-Analytical Support for the Processes of Formation of "Smart Sociopolis" of Truskavets. Proc. 15th Int. Conf. on ICT in Education, Research and Industrial Applications. Integration, Harmonization and Knowledge Transfer (ICTERI2019), Vol. II: Workshops, Kherson, Ukraine, June 12-15 CEUR-WS .org, Vol. 2393. Available at: http://ceur-ws.org/Vol-2393/ (Scopus)

6. Теребух А. А., Кошова Б. Р. (2017). Прогнозування впливу соціально-економічного розвитку на формування туристичної сфери західного регіону України. Ефективна економіка, № 17, С. 5. Available at: http://www.economy.nayka.com.ua/?op=1\&z=5963

7. Одрехівський М. В., Пшик-Ковальська О. О., Побурко О. Я. (2018). Проблеми формування рекреаційної інноваційної інфраструктури агломеративних утворень Карпатського єврорегіону. Ефективна економіка, № 8. Available at: http://www.economy.nayka.com.ua/?op=1\&z=6476. 


\section{O. I. Grytsay, I. A. Hrytsai}

8. Шевчук Л. Т. (2008). Стимулювання регіонального розвитку Закарпатської області: монографія, $241 \mathrm{c.}$

9. Іртищева I. О., Стегней М. І. (2014). Сталий розвиток територіальних одиниць Закарпаття в контексті транскордонного співробітництва. Науковий вісник Мукачівського держ. ун-ту. Серія Економіка, Вип. 2 , C. $47-52$.

10. Білак Г. Г. (2015). Пріоритетні напрями удосконалення територіальної організації розвитку Закарпатської області. Ефективна економіка, № 5. Available at: http://www.economy.nayka.com.ua/?op=1\&z=4110

11. Проскура В. Ф. (2011). Аналіз економічної оцінки в життєвому циклі ресурсів регіону. зб. праць Черкаського держ. технологічного ун-ту. (Серія: Економічні науки), Вип. 28, ч. III, С. 43-46.

12. Чучка I. М., Кобаль Н. М. (2012). Менеджментові засади вдосконалення механізму функціонування Карпатського єврорегіону. Науковий вісник Ужгородського нац. ун-ту. Серія: Економіка. 07/2012, Вип. 35, Ч. 2, C. 257-260.

13. Varchenko O., Shepel T., Utechenko D., Khakhula L., Slobodeniuk O., Byba V., Portyan M. (2019). Key components of sustainable supply chain development of the agricultural sector of Ukraine. International Journal of Supply Chain Management, Vol. 8, No. 2, pp. 874-884. (Scopus)

14. Kozlovskyi S., Mazur H., Vdovenko N., Shepel T., Kozlovskyi V.9 (2018). Modeling and forecasting the level of state stimulation of agricultural production in Ukraine based on the theory of fuzzy logic. Montenegrin Journal of Economics, Vol. 14, No. 3, pp. 37-53. (Scopus)

15. Статистичний щорічник. Державна служба статистики України. Available at: http://ukrstat.gov.ua/ druk/publicat/kat_u/publ1_u.htm

16. Паспорт Закарпатської області. Закарпатська обласна державна адміністрація. Available at: https://carpathia.gov.ua/sites/default/files/imce/190503_pasport-2019.pdf

17. Соціально-економічне становище Закарпатської області: щомісячне повідомлення. Головне управління статистики у Закарпатській області. Available at: http://www.uz.ukrstat.gov.ua/

18. Швець Ю. О., Бурдило О. В. (2017). Оцінка інвестиційного клімату в Україні: стан, проблеми та шляхи його поліпшення. Науковий вісник Ужгородського наи. ун-ту. Серія: Міжнародні економічні відносини та світове господарство, № 12(2), С. 165-168. Available at: http://nbuv.gov.ua/UJRN/Nvuumevcg_2017_12(2)_37.

19. Пилипенко Л. М., Іличок Б. І. (2021). Формування концепції земельної реформи в Україні. Державне управління: удосконалення та розвиток, № 1, C. 5. Available at: http://www.dy.nayka.com.ua/?op=1\&z=1937

20. Головне Управління з питань європейської інтеграції, зовнішньоекономічних зв’язків та туризму Закарпатської обласної державної адміністрації. Available at: http://www.uzez.uz.ua/3.3.html

1. Alieksieiev I. (2014). Budgetary mechanism and socio - economic development of regions: monograph. Lviv: Liga-Pres, 248 p.

2. Savchuk L. (2017). Economic cybernetics: modeling of socio-economic systems monograph Dnipro: Porogy, $480 \mathrm{p}$.

3. Kuzmin O., Stanasiuk N., Yastrubskyi M., Mohylevska O., Artiushok V. (2020). Industrial potential: assessment, modeling and administration under the condition of sustainable development. Naukovyj visnyk National Mining University, No. 6, pp. 128-135. (Scopus).

4. Karyy O., Hlynskyy N. (2020). Mutual Efforts of Territorial Communities for the Purpose of Using their Tourism and Recreational Potential. Effective economy, No 5. Retrieved from: http://www.economy.nayka. com.ua/?op=1\&z=7886

5. Odrekhivskyi M., Kunanets N., Pasichnyk V., Rzheuskyi A., Tabachishin D. (2019). InformationAnalytical Support for the Processes of Formation of "Smart Sociopolis" of Truskavets. Proc. 15th Int. Conf. on ICT in Education, Research and Industrial Applications. [Integration, Harmonization and Knowledge Transfer (ICTERI2019)]. Vol. II: Workshops, Kherson, Ukraine, June 12-15 CEUR-WS .org, Vol. 2393. Retrieved from: http://ceur-ws.org/Vol-2393/ (Scopus)

6. Terebuh A., Koshova B. (2017). Forecasting the influence of socio-economic development on forming the tourism sector of the western region of Ukraine. Effective economy, No. 17. Retrieved from: http://www.economy. nayka.com.ua/?op=1\&z=5963

7. Odrekhivskyi M., Phsyk-Kovalska O., Poburko O. (2018). Problems of formation of recreational innovative infrastructure of aglomerative formations Carpathian Euroregion. Effective economy. No 8. Retrieved from: http://www.economy.nayka.com.ua/?op $=1 \& z=6476$

8. Shevchuk L. (2008). Stimulation of regional development of Zakarpattia region: monograph. Lviv: IRD NAN of Ukraine, $241 \mathrm{p}$. 
Socio-economic analysis of the current state and prospects of development of the Zakarpattia region

9. Irtyscheva I. O. and Stehnej M. I. (2014). Sustainable development units Transcarpathia in the context of cross-border cooperation, Naukovyj visnyk Mukachivs'koho derzhavnoho universytetu. Seriia Ekonomika, Vol. 2, pp. 47-52.

10. Bilak G. (2015) Priority areas for improving the territorial development of the Zakarpattia region. Effective economy, No 5. Retrieved from: http://www.economy.nayka.com.ua/?op=1\&z=4110

11. Proskura V. (2011). Analysis of economic evaluation in the life cycle resources of the region. Zbirnyk prats' Cherkas'koho derzhavnoho tekhnolohichnoho universytetu. Seriia: Ekonomichni nauky. Vol. 28, part III, pp. $43-46$.

12. Chuchka I. M. and Kobal' N. M. (2012). Management principles to improve the mechanism of functioning of the Carpathian Euroregion. Naukovyj visnyk Uzhhorods'koho natsional'noho universytetu. Seriia: Ekonomika. Vol. 35, part 2. pp. 257-260.

13. Varchenko O., Shepel T., Utechenko D., Khakhula L., Slobodeniuk O., Byba V., Portyan M. (2019). Key components of sustainable supply chain development of the agricultural sector of Ukraine. International Journal of Supply Chain Management, Vol. 8, No. 2, pp. 874-884. (Scopus)

14. Kozlovskyi S., Mazur H., Vdovenko N., Shepel T., Kozlovskyi V. (2018). Modeling and forecasting the level of state stimulation of agricultural production in Ukraine based on the theory of fuzzy logic. Montenegrin Journal of Economics, Vol. 14, No. 3, pp. 37-53. (Scopus)

15. State Statistics Service of Ukraine. Retrieved from: http://ukrstat.gov.ua/druk/publicat/kat_u/publ1_u.htm

16. Passport of the Zakarpattia region. Zakarpattia Regional State Administration. Retrieved from: https://carpathia.gov.ua/sites/default/files/imce/190503_pasport-2019.pdf

17. Socio-economic population of Zakarpattia region: Monthly report. Main Department of Statistics in the Zakarpattia region. Retrieved from: http://www.uz.ukrstat.gov.ua/

18. Shvets' Yu. O. and Burdylo O. V. (2017). Estimation of the investment climate in Ukraine: the state, problems and ways of its improvement. Naukovyj visnyk Uzhhorods'koho natsional'noho universytetu, Vol. 12 (2). Retrieved from: http://nbuv.gov.ua/UJRN/Nvuumevcg_2017_12(2)_37

19. Pylypenko L. and Ilychok B. (2021). Formation of the concept of land reform in Ukraine. Derzhavne upravlinnya: udoskonalennya ta rozvytok, Vol. 1. Retrieved from: http://www.dy.nayka.com.ua/?op=1\&z=1937

20. Main Department for European Integration, Foreign Economic Relations and Tourism of the Zakarpattia Regional State Administration. Retrieved from: http://www.uzez.uz.ua/3.3.html

\author{
О. І. Грицай ${ }^{1}$, І. А. Грицай ${ }^{2}$ \\ Національний університет “Львівська політехніка", \\ кафедра обліку та аналізу \\ ORCID: ${ }^{1}$ 0000-0001-6305-9219, ${ }^{2}$ 0000-0003-0630-1317
}

\title{
СОЦІАЛЬНО-ЕКОНОМІЧНИЙ АНАЛІЗ СУЧАСНОГО СТАНУ І ПЕРСПЕКТИВ РОЗВИТКУ ЗАКАРПАТСЬКОЇ ОБЛАСТІ
}

(C) Гриизай O. I., Гриияай I. A, 2021

Досліджено основні статистичні показники Закарпатської області: валовий регіональний продукт (ВРП), інфляцію, економічну активність населення, безробіття, рівень споживчих цін, капітальні вкладення, зовнішньоекономічну діяльність, видатки домогосподарств, рівень заробітної плати та доходів населення у 2007-2019 рр., динаміку яких відображають два кризові періоди: 2008 та 2014-2015 рр. Визначено пріоритетні напрями вдосконалення територіальної організації Закарпатської області, які забезпечать стійкість регіонального розвитку. Унікальне геополітичне розташування Закарпатської області та їі аграрна спрямованість с вирішальними факторами для подолання криз та пожвавлення соціально-економічного розвитку регіону.

Ключові слова: економічний розвиток регіону; ВРП; інфляція; економічна активність населення; безробіття; рівень споживчих цін; капітальні інвестиції; витрати домогосподарств; рівень заробітної плати та доходів населення. 